\title{
Deficiency of the Adenine Nucleotide Translocator in Muscle of a Patient with Myopathy and Lactic Acidosis: A New Mitochondrial Defect
}

\author{
HENK D. BAKKER, HANS R. SCHOLTE, COBY VAN DEN BOGERT, WIM RUITENBEEK. \\ JEROEN A. L. JENESON, RONALD J. A. WANDERS. NICO G. G. M. ABELING. BERT DORLAND. \\ ROB C. A. SENGERS, AND ALBERT H. VAN GENNIP \\ "Het Emma Kinderziekenhuis"/Children's Academic Medical Centre, Amsterdam /H.D.B., R.J.A. U \\ N.G.G.M.A., A.H.V.G.I: the Department of Biochemistry, Erasmus University. Rotterdam [H.R.S. I: the E. C. \\ Slater Institute for Biochemical Research. University of Amsterdam /C.V.D.B.]: the Division of Pediatrics. \\ University of Nijmegen [W.R., R.C.A.S.]: and "Het Wilhelminia Kinderziekenhuis," University Children's \\ Hospital, Utrecht [J.A.L.J., B.D.J, The Netherlands
}

\begin{abstract}
In a patient with a mitochondrial myopathy, presenting with lactic acidosis, ${ }^{31} \mathrm{P}$-nuclear magnetic resonance spectroscopy in resting muscle showed half the creatine phosphate level of controls. The creatine phosphate resynthesis rate after aerobic exercise was only $18 \%$ of that in controls. However, the activities of complexes I to $\mathrm{V}$ catalyzing oxidative phosphorylation and the pyruvate and the 2-oxoglutarate dehydrogenase complexes showed a 2- to 20-fold increase. In line with this, the uncoupled mitochondrial respiration rate was significantly higher than in controls. In contrast, the respiration of the mitochondria from the patient was less stimulated by ADP than that of control mitochondria. This finding could point to a defect in complex $\mathrm{V}$, the enzyme directly involved in ATP synthesis. The activity of complex $\mathrm{V}$, measured as the mitochondrial ATPase activity, and its concentration, as judged from Western blots using antisera against the $F_{1}$ part of complex $\mathbf{V}$, were, however, also greatly increased in the patient. Alternatively, the transport system, importing ADP into and exporting ATP out of the mitochondrial matrix, the $\mathrm{ADP} / \mathrm{ATP}$ or adenine nucleotide translocator, could be affected. Immunostaining of Western blots revealed a 4fold decrease in the concentration of the adenine nucleotide translocator in the patient. Because oxidative phosphorylation was not disturbed in fibroblasts and lymphocytes, we conclude that this patient suffers from a muscle-specific deficiency of his mitochondrial adenine nucleotide translocator, a defect unknown so far. (Pediatr Res 33: 412417, 1993)
\end{abstract}

\section{Abbreviations}

${ }^{31} \mathrm{P}-\mathrm{NMR},{ }^{31} \mathrm{P}$-nuclear magnetic resonance

$\mathrm{Pi}$, inorganic phosphate

The major function of mitochondria is to provide energy in the form of ATP and, in muscle and brain, as creatine phosphate,

Received July 23, 1992: accepted November 11. 1992

Correspondence: Dr. H. D. Bakker, "Het Emma kinderziekenhuis"/Children's Academic Medical Centre. University of Amsterdam, Meibergdreef 9, $1105 \mathrm{AZ}$ Amsterdam. The Netherlands.

Supported by grants from "Het Prinses Beatrix Fonds," The Hague. The Netherlands, and a grant from the Roval Netherlands Academy of Arts and Sciences, Amsterdam. The Netherlands. which enables the cells to perform a variety of energy-consuming processes. Mitochondrial energy production requires the uptake of substrates by several import systems, the conversion of these substrates to oxidizable compounds, and, finally, oxidative phosphorylation. During the latter process, electrons derived from oxidizable substrates are transported via the enzymes of the respiratory chain to oxygen (respiration), and a proton gradient is generated over the mitochondrial inner membrane. This gradient is the driving force for the production of ATP by complex $\mathrm{V}$, the ATP synthase (phosphorylation). ATP produced inside the mitochondria is next transported to the cytosol by the adenine nucleotide translocator. This carrier is also responsible for the import of ADP into the mitochondria: ADP is exchanged for ATP.

Mitochondrial defects that impinge directly on mitochondrial energy metabolism can thus be based on dysfunction of one or more of the enzymes involved in the processes described above (1). In addition, many of the enzyme complexes involved in mitochondrial energy production occur as tissue-specific isoforms. Muscle-specific isoforms of complex IV (cytochrome $c$ oxidase) (2) and the adenine nucleotide translocator (3-6) have. for instance, clearly been established. Tissue-specific mitochondrial enzyme defects are therefore also conceivable.

This communication describes investigations of a boy in whom the clinical presentation was strongly suggestive of a mitochondrial myopathy. These myopathies are characterized by structural and/or functional abnormalities of the mitochondria (1, 7-10). Most of the patients suffering from these diseases show an increased lactate level and/or abnormal concentration of organic acids in body fluids. Usually, one or more of the enzymes involved in mitochondrial energy production is found to be deficient. In the boy under study, however, we found an impressively increased activity of all the mitochondrial enzymes that can be tested in a muscle biopsy. This required further investigations into the nature of the defect, using alternative approaches.

\section{MATERIALS AND METHODS}

Patient. A boy (B. H.), second child of healthy, nonconsanguineous parents, was admitted at the age of $3.5 \mathrm{y}$ because of shortness of breath and rapid fatigue. From delivery in 1983, he had a normal psychologic development, but he did not walk until the age of $18 \mathrm{mo}$, indicative of some motor retardation. 
Clinical and neurologic investigations showed a slightly dystrophic child with a normal muscle tone.

In serum, lactate was $11.8 \mathrm{mM}$ (controls $<2.0$ ), pyruvate 151 $\mu \mathrm{M}$ (controls 41-70), and alanine $453 \mu \mathrm{M}$ (controls 150-300). In cerebrospinal fluid, lactate was $3.3 \mathrm{mM}$ (controls $<1.8$ ) and alanine $38 \mu \mathrm{M}$ (controls 12-32). In urine, the concentration of lactate was also increased $(13.9 \mathrm{mmol} / \mathrm{mmol}$ creatinine $)$ and high levels of ketone bodies were found. Free and total carnitine levels were normal in blood and urine.

Histochemical examination of muscle (musculus quadriceps) showed no ragged red fibers. Electron microscopy revealed abnormal mitochondria containing crystalline structures. Biochemical investigations of a homogenate from frozen muscle demonstrated increased activities of the respiratory chain enzymes and complex V, pyruvate dehydrogenase, and 2-oxoglutarate dehydrogenase.

In the absence of clues pointing to the nature of this disease, and because of its severity, a therapeutic trial was initiated with L-carnitine $(2 \mathrm{~g} / \mathrm{d})$, thiamine $(300 \mathrm{mg} / \mathrm{d})$, riboflavin $(150 \mathrm{mg} / \mathrm{d})$, nicotinamide $(150 \mathrm{mg} / \mathrm{d})$, biotin $(20 \mathrm{mg} / \mathrm{d})$, pantothenic acid $(50$ $\mathrm{mg} / \mathrm{d})$, and lipoic acid $(10 \mathrm{mg} / \mathrm{d})$. This resulted in an apparent temporary improvement of his clinical condition and a decrease of blood lactate to values of 5 to $7 \mathrm{mM}$.

After $23 \mathrm{mo}$, his clinical condition worsened again and serum lactate increased. Because of the possibility of a subtle defect in complex I or coenzyme Q not detectable in frozen muscle (11), menadione $(75 \mathrm{mg} / \mathrm{d})$ and succinate $(3 \mathrm{~g} / \mathrm{d})$ were given orally but remained without effect. A second muscle biopsy was taken for investigations of intact mitochondria. Whereas most mitochondrial enzyme activities in the homogenate again were found to be increased, oxidative phosphorylation by intact mitochondria was defective. This was confirmed by in vivo ${ }^{31} \mathrm{P}-\mathrm{NMR}$ spectroscopy of the muscle.

After discontinuation of the therapeutic measures, the patient's appetite improved, but serum lactate rose to $12.7 \mathrm{mM}$ and pyruvate to $286 \mu \mathrm{M}$, and ${ }^{31} \mathrm{P}-\mathrm{NMR}$ spectroscopy showed the same results as before. He attends a normal school and is among the best pupils of his class in all subjects except gymnastics.

Muscle biochemistry of first biopsy. The assays on muscle from the first biopsy were performed in homogenates. Protein, total carnitine, the activities of total creatine kinase, rotenone-sensitive NADH oxidase (complex I), succinate dehydrogenase (complex II), antimycin-sensitive succinate-cytochrome $c$ reductase (complex II + III), and cytochrome c oxidase (complex IV) were measured as described by Scholte et al. (11).

Oligomycin-sensitive, uncoupler-stimulated $\mathrm{Mg}^{2+}$-ATPase (complex V) activity was measured as described by Scholte $e t$ al. (11), in the presence of the uncoupler 2,4-dinitrophenol (and $2.5 \%$ ethanol) as the difference between the activity with and without oligomycin $(25 \mu \mathrm{g} / \mathrm{mL})$. Pyruvate dehydrogenase activity was measured after preincubation with $\mathrm{Mg}^{2+}$-ATP followed by $\mathrm{Ca}^{2+}$ plus $\mathrm{Mg}^{2+}$. The activity of this enzyme and also of the 2oxoglutarate dehydrogenase complex was measured according to Arts et al. (12).

Muscle biochemistry of second biopsy. Because of the limited amount of biopsy material, isolation and purification of mitochondria was excluded. Activities of oxidative phosphorylation in the second biopsy were therefore measured in a supernatant ( $10 \mathrm{~min}, 600 \times \mathrm{g}$ ) of a homogenate of freshly biopsied muscle, which is an appropriate alternative for isolated mitochondria $(13,14)$.

The activities of total creatine kinase, rotenone-sensitive NADH-ubiquinone-1 oxidoreductase (complex I), succinate-cytochrome $c$ reductase (complex II + III), cytochrome $c$ oxidase (complex IV), pyruvate dehydrogenase, 2-oxoglutarate dehydrogenase, citrate synthase, as well as substrate oxidation rates and ATP production rates of intact mitochondria, were assayed as described by Fischer et al. (13) and Van Laack et al. (14). The final concentration of the uncoupler $m$-chlorocarbonyl cyanide phenylhydrazine was $2 \mu \mathrm{M}$. Mitochondrial creatine kinase was determined according to the method outlined by Smeitink et al. (15). The other assays were as described for the first biopsy

Patients suspected of having a neuromuscular disorder, without biochemical and morphologic evidence of such a disorder were taken as controls. The age of the controls was between 2 mo and $60 \mathrm{y}$. For this age range, no statistically significant differences were found for the activities and amounts measured between different age groups or between males and females.

'P-NMR spectroscopy. ${ }^{3 !} \mathrm{P}-\mathrm{NMR}$ spectroscopic measurement of in vivo levels of creatine phosphate, ATP, and Pi in skeletal muscle in the resting state was performed at the age of 5, 7, and 8 using a 1.5 T Philips S15/HP Gyroscan unit (Philips Medical Systems, Best, The Netherlands). In addition, the rate of creatine phosphate resynthesis after aerobic exercise, reflecting the in vivo capacity of mitochondrial ATP synthesis (16-18), was measured at the age of $8 \mathrm{y}$.

The patient was positioned prone and head-first on the patient bed, with his right arm extended forward. The muscle belly of the forearm was placed over a 5 -cm single-turn double-tunable ${ }^{1} \mathrm{H} /{ }^{31} \mathrm{P}$ surface coil. The sampled muscle mass consisted of both finger and wrist flexor muscles. After adjustment of the local Bo field homogeneity $(0.25-0.33 \mathrm{ppm}),{ }^{31} \mathrm{P}-\mathrm{NMR}$ spectra of superficial skeletal muscle of the forearm were obtained at $25.86 \mathrm{MHz}$, using an adiabatic half-passage excitation pulse with a length of $3 \mathrm{~ms}$, sweep width $3 \mathrm{kHz}$ ( 1024 points), and repetition time of 3 $\mathrm{s}$. For the measurement of relative creatine phosphate, ATP, and $\mathrm{Pi}$ levels in skeletal muscle in the resting state, 100 acquisitions were averaged. During the creatine phosphate recovery measurement. ${ }^{31} \mathrm{P}-\mathrm{NMR}$ spectra were obtained at rest, during aerobic steady-state exercise, and during recovery in 1-min blocks for 10 min. Exercise was performed by squeezing a plastic air bulb once ever 4 s during $3 \mathrm{~min}$.

Free induction decays were processed on a Sun Sparc 330 workstation, using the LAB ONE (New Methods Research, Inc., Syracuse, New York) NMRI spectroscopy processing software. The decays were exponentially filtered, resulting in a $10-\mathrm{Hz}$ line broadening, and zero-filled to 2048 data points before Fourier transformation. After manual phasing, baseline correction was performed by baseline deconvolution using computer-estimated flattening parameters. Estimates of the relative peak areas of the phosphates were obtained by curve fitting of the spectrum of Lorentzian line shapes. Global intracellular $\mathrm{pH}$ was estimated from the chemical shift of Pi relative to creatine phosphate.

The time constants $k$ of the creatine phosphate resynthesis rate and the Pi disappearance rate were estimated from the fit of the changes in creatine phosphate (expressed as percentages of the initial levels) with time to a single exponential function (18) using the Enzfitter software (version 1.05, Elsevier Biosoft, Cambridge, UK). Statistical comparisons were made using a paired $t$ test.

Muscle immunobiochemistry of second biopsy. Frozen muscle biopsies (about $50 \mathrm{mg}$ ) were homogenized and suspended to $10 \%$ (mass $/ \mathrm{vol})$ in ice-cold buffer $(0.25 \mathrm{M}$ sucrose, $1 \mathrm{mM}$ Tris- $\mathrm{HCl}$. $\mathrm{pH} 7.4$ ) containing a mixture of protease inhibitors (19). Laurylmaltoside (final concentration $1.5 \%$ ) was added to the homogenate to solubilize the proteins. The samples were directly used or stored in liquid nitrogen. The proteins in the samples were resolved by polyacrylamide gel electrophoresis in the presence of sodium dodecyl sulfate. Western blotting and immunodetection of the proteins were performed as described elsewhere (19). Polyclonal antisera against the $F_{1}$ part of complex $\mathrm{V}$ and the adenine nucleotide translocator, both isolated from rat liver mitochondria, were a kind gift of Dr. K. Luciaková and coworkers (Cancer Research Institute, Bratislava, Czechoslovakia). These antisera showed a clear cross-reactivity with the respective mitochondrial proteins from both human liver and human muscle. Antisera against cytochrome $c$ oxidase from bovine heart were obtained as described before (19).

Formation of lactate and pyruvate from glucose in cultured skin fibroblasts. Human skin fibroblasts were grown from ex- 
plants of skin biopsies of healthy individuals and our patient in HAM F-10 medium (Flow Laboratories, Irvine, Scotland), supplemented with $7.5 \%(\mathrm{vol} / \mathrm{vol}) \mathrm{FCS}, 7.5 \%(\mathrm{vol} / \mathrm{vol})$ newborn calf serum, $3 \mathrm{mM}$ glutamine, $10 \mathrm{mM} \mathrm{NaHCO}_{3}, 20 \mathrm{mM}$ HEPES $(N$ 2-hydroxyethylpiperazine- $N^{\prime}$-2-ethanesulfonic acid), $100 \mathrm{U} / \mathrm{mL}$ penicillin, $100 \mu \mathrm{g} / \mathrm{mL}$ streptomycin, and $0.25 \mu \mathrm{g} / \mathrm{mL}$ fungizone in an atmosphere of $5 \%(\mathrm{vol} / \mathrm{vol})$ carbon dioxide in air. To study glucose metabolism, cells were grown in $25-\mathrm{cm}^{2}$ culture flasks and incubated in a medium containing Krebs-Henseleit bicarbonate buffer plus $20 \mathrm{mM}$ HEPES ( $\mathrm{pH} \mathrm{7.4)}$ ) and $5 \mathrm{mM}$ glucose. The production of lactate and pyruvate was measured after $4 \mathrm{~h}$ at $37^{\circ} \mathrm{C}$

ATP synthesis in permeabilized lymphocytes. Lymphocytes were isolated according to standard procedures from blood obtained from control subjects and our patient, and finally suspended in PBS ( $140 \mathrm{mM} \mathrm{NaCl}, 9.2 \mathrm{mM} \mathrm{Na}_{2} \mathrm{HPO}_{4}$, and $1.3 \mathrm{mM}$ $\mathrm{NaH}_{2} \mathrm{PO}_{4}, \mathrm{pH} 7.4$ ) plus $1 \%$ (wt/vol) BSA (fatty acid-free). Subsequently, the lymphocytes (final concentration $0.3 \mathrm{mg}$ protein/ $\mathrm{mL}$ ) were incubated in a medium containing $150 \mathrm{mM} \mathrm{KCl}, 25$ $\mathrm{mM}$ Tris- $\mathrm{HCl}, 2 \mathrm{mM}$ sodium EDTA, $10 \mathrm{mM}$ potassium phosphate (final $\mathrm{pH} 7.4$ ), plus $75 \mu \mathrm{g} / \mathrm{mL}$ digitonine to permeabilize the cells. After $5 \mathrm{~min}$ at $25^{\circ} \mathrm{C}$, ATP synthesis was initiated by adding ADP (final concentration $10 \mathrm{mM}$ ) and oxidizable substrates, which included $10 \mathrm{mM}$ glutamate plus $10 \mathrm{mM}$ malate. $10 \mathrm{mM}$ pyruvate plus $10 \mathrm{mM}$ malate, $20 \mathrm{mM}$ succinate (in the presence of $20 \mu \mathrm{g} / \mathrm{mL}$ rotenone), and $10 \mathrm{mM}$ ascorbate plus 0.5 $\mathrm{mM}$ N,N, N'-N'-tetramethyl-p-phenylenediamine-dihydrochloride. Reactions were terminated after $10 \mathrm{~min}$ by adding perchloric acid $(0.5 \mathrm{~N}$ final concentration). Subsequent work-up of samples and measurement of ATP was done as described before (21).

\section{RESULTS}

Muscle biochemistry. The activities of a number of enzymes as measured in muscle homogenates of the patient are shown in Table 1. In the first biopsy (before treatment), the activity of respiratory chain enzymes (complexes I, II, II + III, and IV), as well as the activities of complex $\mathrm{V}$, pyruvate dehydrogenase, and 2-oxoglutarate dehydrogenase, were 1.9- to 19.9-fold increased, whereas the muscle contents of protein, total carnitine, and the total creatine kinase activity were in the normal range.

The second muscle biopsy (during treatment) showed that the activities of citrate synthase and mitochondrial creatine kinase also were strongly increased and confirmed the increased activities of complexes I, II, II + III, V and 2-oxoglutarate dehydrogenase. The activity of pyruvate dehydrogenase was again found to be increased but less than in the first biopsy. The activity of cytochrome $c$ oxidase had normalized (Table 1).

The mitochondrial capacity to oxidize pyruvate plus malate and the resulting energy production were measured in a supernatant prepared from freshly biopsied muscle (Table 2). The oxidation rate of pyruvate was stimulated by ADP by a factor of 2.7, compared with 7.0 in the average controls, and addition of uncoupler $m$-chlorocarbonyl cyanide phenylhydrazine stimulated the oxidation rate by a factor of 15.7 , compared with 7.0 in the controls, to an abnormally high value of $1974 \mathrm{nmol}{ }^{14} \mathrm{CO}_{2}$. $\mathrm{h}^{-1} \cdot(\mathrm{mg} \text { protein })^{-1}$ versus a control range of 260 to 700 . Coupled and uncoupled respiration show about the same velocity in the controls. From the great difference between these activities in the patient, it can be concluded that the patient has a severe defect in the mitochondrial phosphorylation.

The phosphorylation defect was further supported by the finding that the energy production from pyruvate plus malate was barely normal. This resulted in a molar ratio of high-energy phosphates over pyruvate oxidized of 5.4 in the patient versus 10.0 in the average controls.

The phosphorylation defect is unlikely to result from a deficiency of complex $\mathrm{V}$ because the activity of this complex, meas- ured as mitochondrial ATPase, was increased 4.7-fold compared with controls (Table 1).

${ }^{31} P-N M R$ spectroscopy. An overview of the relative creatine phosphate, $\mathrm{Pi}$, and ATP content, and the intracellular $\mathrm{pH}$ of the patient's skeletal muscle in the resting state versus healthy controls, is given in Table 3. Most importantly, the creatine phosphate content of the patient's skeletal muscle was significantly decreased by a factor of 2 in comparison with controls $(p<$ $0.01)$, whereas the $\mathrm{Pi}$ content was significantly increased $(p<$ $0.01)$. Intracellular $\mathrm{pH}$ was normal. These findings were similar for all three examinations conducted at different ages ( 5 to $8 \mathrm{y}$ ).

In the creatine phosphate recovery measurement conducted at the age of $8 \mathrm{y}$, the ${ }^{31} \mathrm{P}-\mathrm{NMR}$ spectra obtained during exercise showed that the global intracellular $\mathrm{pH}$ within the sampled muscle mass had only slightly decreased to 6.95. This absence of any significant intracellular acidosis validated fitting of the creatine phosphate recovery kinetics to a single exponential function (18). The global creatine phosphate content of the sampled muscle mass had decreased to $50 \%$ of its initial value during exercise. The time constant $k$ for the rate of creatine phosphate recovery to the resting level was significantly decreased in the patient's skeletal muscle to $18 \%$ of that in healthy controls (Table $3)$. In the recovery phase, the rate of Pi disappearance was $24 \%$ of that in controls. This decrease is to be expected because the charge difference resulting from $\mathrm{ATP}^{4-}$ export and $\mathrm{ADP}^{3-}$ import necessitates the respiratory chain to export $1 \mathrm{H}^{+}$, which recycles back to the matrix with $\mathrm{H}_{2} \mathrm{PO}_{4}{ }^{-}$by the action of the phosphate translocator. This activity must be in pace with that of the adenine nucleotide translocator to maintain electroneutrality. The fact that the rate of $\mathrm{Pi}$ disappearance was higher than that of creatine phosphate recovery (Table 3 ) suggests that the pacing is not as strict and the phosphate translocator is not rate-limiting in creatine phosphate resynthesis.

Immunobiochemistry of muscle. For the analysis of the concentration of mitochondrial enzymes, gels were loaded with samples from patient and control muscle homogenates that contained a comparable amount of protein. Differences in the mobility of immunoreactive subunits were not observed after immunostaining of blots incubated with antisera against $F_{1}$ of complex V and cytochrome $c$ oxidase (Fig. 1) and the adenine nucleotide translocator (Fig. 2). However, differences in the concentration of the respective proteins were clearly visible. The concentration of immunoreactive subunits of cytochrome $c$ oxidase as well as $F_{1}$ in the samples from the patient showed a 5to 10-fold increase compared with the control, whereas protein, immunoreacting with adenine nucleotide translocator antiserum was about 4-fold decreased. This agreed with the increased activity of the $F_{1}$-ATPase (complex V in Table 1) but contrasted with the normal activity of cytochrome $c$ oxidase (complex IV in Table 1).

Oxidative phosphorylation in fibroblasts and lymphocytes. To detect if the defect was expressed in cell types other than muscle, studies were performed in cultured skin fibroblasts and lymphocytes. In fibroblasts of the patient, the production of lactate and pyruvate from glucose, as well as the lactate/pyruvate ratio, was normal. Pyruvate carboxylase also showed a normal activity.

In permeabilized lymphocytes, we measured the synthesis of ATP from ADP plus phosphate using the various oxidative substrates. The results showed normal rates of ATP synthesis with each of the different substrates.

\section{DISCUSSION}

To the best of our knowledge, this is the first description of a patient with a mitochondrial myopathy in whom all the available evidence points to a muscle-specific deficiency of the adenine nucleotide translocator as the primary cause of the disease. The most direct evidence to support this conclusion is the decreased amount of protein immunoreacting with an antiserum against the adenine nucleotide translocator in the muscle of the patient. 
Table 1. Concentrations of protein and carnitine and activities of total creatine kinase and mitochondrial enzymes in muscle biopsies from patient and controls*

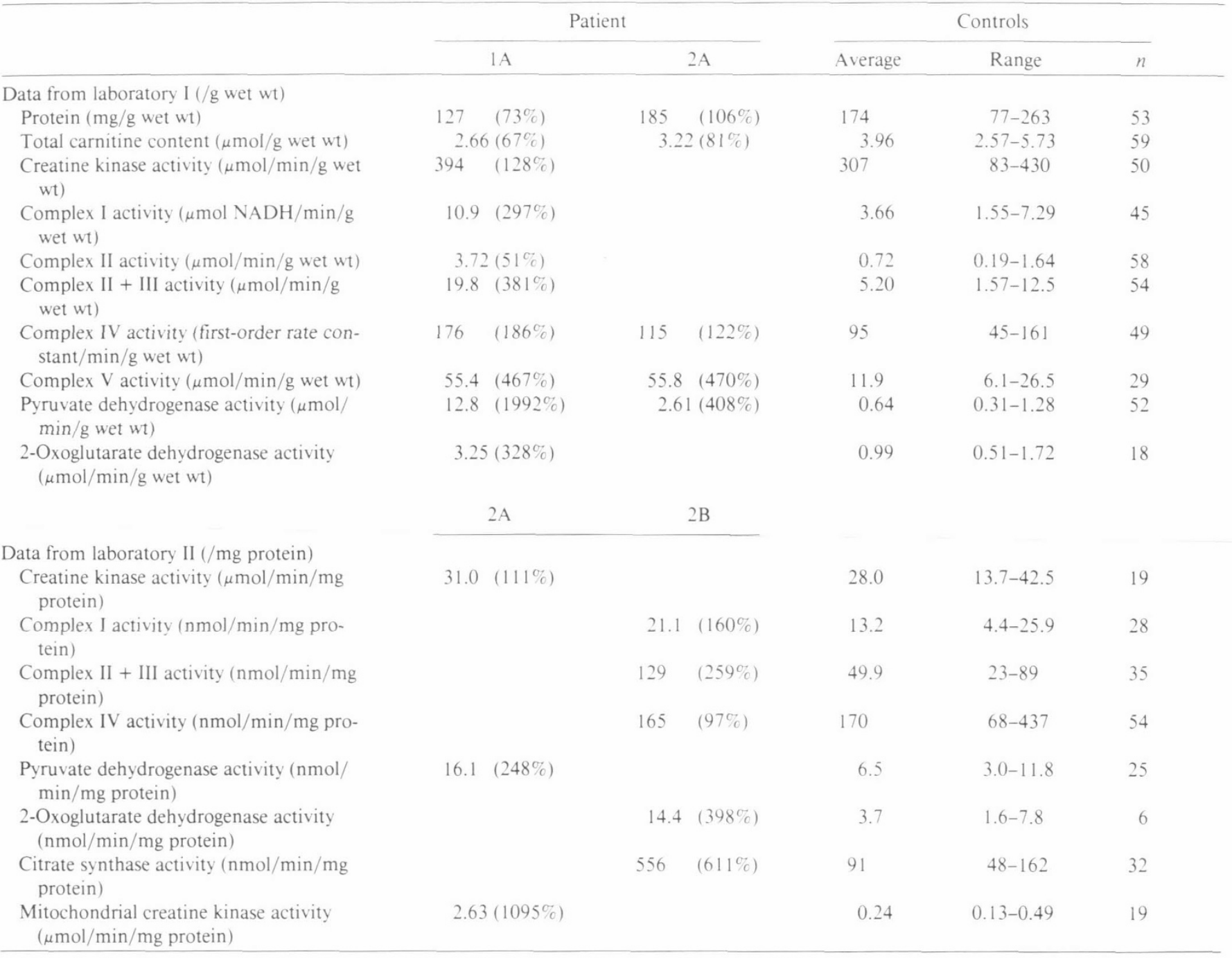

* 1 is the first biopsy at age $3.5 \mathrm{y}$ before treatment and 2 the second biopsy at the age of $5.5 \mathrm{y}$ on treatment. A, muscle homogenate; B, 10-min $600 \times g$ supernatant: $n$, no. of controls. Enzyme activities are expressed in indicated amount of substrate $/ \mathrm{min}$.

Table 2. Activities of mitochondrial oxidative phosphorylation in 10-min $600 \times \mathrm{g}$ supernatant of freshly biopsied muscle (second biopsy)*

\begin{tabular}{|c|c|c|c|c|}
\hline & \multirow[b]{2}{*}{ Patient } & \multicolumn{2}{|c|}{ Controls } & \multirow[b]{2}{*}{$n$} \\
\hline & & Mean & Range & \\
\hline \multicolumn{5}{|l|}{ Oxidation of } \\
\hline$\left[1-{ }^{14} \mathrm{C}\right]$ pyruvate + malate + ADP & 338 & 473 & $273-705$ & 19 \\
\hline$\left[1-{ }^{14} \mathrm{C}\right]$ pyruvate + malate + CCCP & 1974 & 460 & $260-700$ & 19 \\
\hline $\begin{array}{l}\text { Production of high energy phosphates with pyruvate }+ \\
\text { malate + ADP + creatine }\end{array}$ & 1811 & 4747 & $1833-8750$ & 25 \\
\hline
\end{tabular}

*The activities are expressed in nmol $\mathrm{CO}_{2}$ or high-energy phosphates produced $\cdot \mathrm{h}^{-1} \cdot(\mathrm{mg} \text { protein })^{-1}$. $n$, number of controls; CCCP, $m$ chlorocarbonyl cyanide phenylhydrazine, an uncoupler of oxidative phosphorylation.

This antiserum was raised against the adenine nucleotide translocator, isolated as described by Schultheiss et al. (22), from rat liver mitochondria. It shows a highly specific reactivity to the adenine nucleotide translocator of various mammalian species, including man (data not shown), and reacts indiscriminately with the different tissue-specific isoforms of the translocator.

The decrease in adenine nucleotide translocator protein in the patient could be explained by decrease in antigeneity of a mutant protein. However, the faint translocator band in the patient could also reflect a deficiency of the muscle-specific adenine nucleotide translocator isoform, an explanation strongly supported by the tissue specificity of the mitochondrial defect. Moreover, preliminary results of transcript analysis with isoform-specific probes show a severely reduced level of the transcript of the musclespecific adenine nucleotide translocator gene in the patient's muscle as compared with controls.

Regardless of the precise genetic nature of the defect, deficiency of the adenine nucleotide translocator fully explains the results obtained in the functional analysis of the muscle mitochondria from the patient. The decreased stimulation of respiration by 
Table 3. Relative creatine phosphate ATP and Pi levels and intracellular $\mathrm{pH}$ in superficial skeletal muscle of the forearm in resting state, and the time constant $k$ of creatine phosphate recovery and $P i$ disappearance after exercise

\begin{tabular}{|c|c|c|c|c|c|}
\hline & \multicolumn{3}{|c|}{ Patient age $(\mathrm{y})$} & \multicolumn{2}{|l|}{ Controls } \\
\hline & 5 & 7 & 8 & Mean \pm SD & $n$ \\
\hline \multicolumn{6}{|l|}{ Resting muscle } \\
\hline $\mathrm{Pi} / \mathrm{PCr}$ & 0.32 & 0.37 & 0.30 & $0.10 \pm 0.01$ & 25 \\
\hline $\mathrm{Pi} / \mathrm{ATP}$ & 0.54 & 0.58 & 0.52 & $0.32 \pm 0.05$ & 25 \\
\hline $\mathrm{PCr} / \mathrm{ATP}$ & 1.69 & 1.50 & 1.70 & $3.17 \pm 0.25$ & 25 \\
\hline $\mathrm{pHi}$ & 7.04 & 7.04 & 7.04 & $7.04 \pm 0.03$ & 25 \\
\hline \multicolumn{6}{|l|}{ Muscle after exercise } \\
\hline \multicolumn{6}{|l|}{ Time constant $k\left(\mathrm{~s}^{-1}\right)$} \\
\hline PCr recovery & & & 0.0045 & $0.0256 \pm 0.0054$ & 19 \\
\hline Pi disappearance & & & 0.0061 & $0.0253 \pm 0.0053$ & 11 \\
\hline
\end{tabular}

* $\mathrm{pHi}$; intracellular $\mathrm{pH}$; $\mathrm{PCr}$, creatine phosphate.

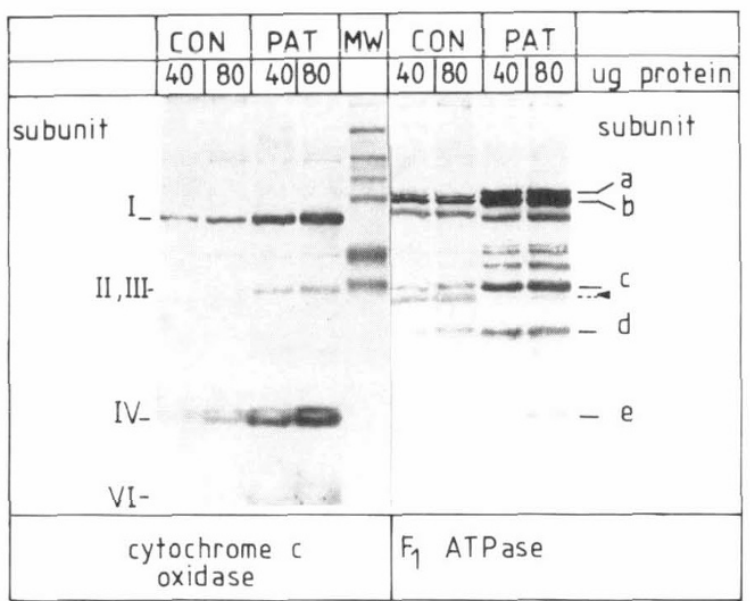

Fig. 1. Analysis of the amounts of cytochrome $c$ oxidase and $F_{1}$ ATPase in muscle homogenates of control and patient. Proteins were resolved by SDS-PAGE, blotted onto nitrocellulose, and treated with antisera against cytochrome $c$ oxidase or $F_{1}$ ATPase, the $F_{1}$ part of complex V. The amount and source of the samples is indicated at the top of the figure; the position of the subunits is indicated at the left and right. The subunits were identified by their apparent molecular masses and by using purified cytochrome $c$ oxidase or $F_{1}$ ATPase as references. Pat, patient; Con, control. $M W$, prestained molecular weight markers, from bottom to top: triosephosphate isomerase, $27 \mathrm{kD}$; lactic dehydrogenase, $37 \mathrm{kD}$; fumarase, $49 \mathrm{kD}$; pyruvate kinase, $58 \mathrm{kD}$; fructose-6phosphate kinase, $84 \mathrm{kD}$; and $\beta$-galactosidase, $116 \mathrm{kD}$. Arrow, adenine nucleotide translocator for which the $F_{1}$ ATPase antiserum shows crossreactivity

ADP and the increase in respiration by uncoupler have to be expected in tightly coupled mitochondria with a high ATP/ADP in the matrix as a consequence of the adenine nucleotide translocator deficiency.

The increased activity of almost all other mitochondrial enzymes might be a secondary effect: hyperproliferation of mitochondria or an enhanced synthesis of mitochondrial enzymes is a common phenomenon in patients with mitochondrial myopathies and might be regarded as an attempt to compensate for the decreased function of individual mitochondria. Compared with the other mitochondrial enzymes, the activity of complex IV was much less increased in the first biopsy and normal in the second one. However, the amount of immunoreactive protein of complex IV was increased several-fold. The nature of this discrepancy between concentration and activity is not known and deserves further research.

Despite the increase in the capacity for (uncoupled) respiration, reflecting the increased activity of the enzymes involved, the energy production of the mitochondria in the muscle of the

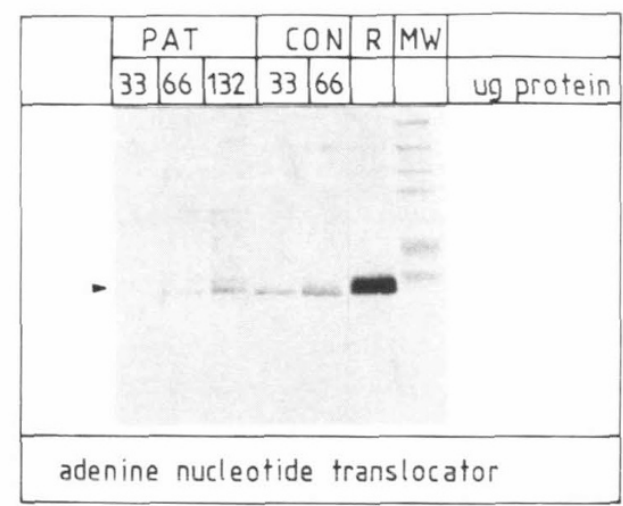

Fig. 2. Analysis of the amount of adenine nucleotide translocator in muscle homogenates of control and patient. $R$, rat liver mitochondria, 5 $\mu \mathrm{g}$ protein; arrow, adenine nucleotide translocator. For additional details, see legend to Figure 1.

patient was severely affected, as is most clearly illustrated by the ${ }^{31} \mathrm{P}-\mathrm{NMR}$ data. A $50 \%$ decrease in creatine phosphate levels in the resting muscle is encountered only in patients with severe defects in mitochondrial energy metabolism. Impairment of oxidative phosphorylation will lead to the accumulation of glycolytic NADH and pyruvate. In turn, this leads to an enhanced production of lactate in the muscle of the patient. Excess lactate will be pumped away to the blood. The severity of the metabolic block is further demonstrated by the very high lactate levels in the blood of the patient. The increased lactate level in the cerebrospinal fluid is possibly due to overflow from the blood compartment, where the level is much higher.

Liver and heart were, according to clinical investigations, completely healthy. Also, involvement of the brain is not likely in light of the patient's intellectual abilities. Moreover, investigations of lymphocytes and fibroblasts did not show indications of abnormal oxidative phosphorylation.

Taken together, the results indicate that the patient described has a mitochondrial disease that is confined to his skeletal muscle, and all the evidence points to a deficiency of the adenine nucleotide translocator as the primary cause. Inhibition of the function of the adenine nucleotide translocator has been reported to occur in secondary mitochondrial pathology (23-28). In these patients, however, the clinical pattern, including the type of organs and tissues involved, is completely different. Moreover, although in these patients the activity of the adenine nucleotide translocator is affected, the concentration of the protein is not. Therefore, the most likely explanation for the molecular background of the muscle-specific disease in our patient is an impaired expression of the gene encoding the muscle-specific form of the adenine nucleotide translocator.

Acknowledgments. The authors thank Pieter A. Bolhuis for his help in molecular biologic studies, and Jacqueline A. M. C. Boonman, Henk L. Dekker, Christel J. Evertsen, Mieke M. van Galen, and John D. Ross for skillful technical assistance.

\section{REFERENCES}

1. Scholte HR 1988 The biochemical basis of mitochondrial diseases. J Bioenerg Biomembr 20:161-192

2. Kennaway NG, Carrero-Valenzuela RD. Ewart G. Balan VK. Lightowler R. Zhang YZ, Powell BR, Capaldi RA, Buist RM 1990 Isoforms of mammalian cytochrome $c$ oxidase: correlation with human cytochrome $c$ oxidase deficiency. Pediatr Res 28:529-535

3. Neckelmann N, Li K, Wade RP, Shuster R, Wallace DC 1987 cDNA sequence of a human skeletal muscle ADP/ATP translocator: lack of a leader pcptide. divergence from a fibroblast translocator cDNA. and coevolution with mitochondrial DNA genes. Proc Natl Acad Sci USA 84:7580-7584

4. Houldsworth J, Attardi G 1988 Two distinct genes for ADP/ATP translocase are expressed at the mRNA level in adult human liver. Proc Natl Acad Sci USA 85:377-381

5. Powell SJ. Medd SM, Runswick MJ, Walker JE 1989 Two bovine genes for 
mitochondrial ADP/ATP translocase expressed differently in various tissues. Biochemistry 28:866-873

6. Lunardi J, Attardi G 1991 Differential regulation of expression of the multiple ADP/ATP translocase genes in human cells. J Biol Chem 266:16534-16540

7. DiMauro S. Bonilla E. Zeviani M. Nakagawa M, DeVivo DC 1985 Mitochondrial myopathies. Ann Neurol 17:521-538

8. Morgan-Hughes JA 1986 In: Engel AG. Banker BQ (eds) Myology. McGrawHill, New York. pp 1709-1743

9. Przyrembel H 1987 Therapy of mitochondrial disorders. J Inher Metab Dis 10(suppl 1):129-146

10. Sengers RCA. Stadhouders AM. Trijbels JMF 1984 Mitochondrial myopathies: clinical. morphological and biochemical aspects. Eur J Pediatr 141:192-207

11. Scholte HR, Busch HFM, Luyt-Houwen IEM, Vaandrager-Verduin MHM, Przyrembel H. Arts WFM 1987 Defects in oxidative phosphorylation. Biochemical investigations in skeletal muscle and expression of the lesion in other cells. J Inher Metab Dis 10(suppl 1):81-97

12. Arts WFM, Scholte HR, Loonen MCB, Przyrembel H, Fernandes J. Trijbels JMF. Luyt-Houwen IEM 1987 Cytochrome $c$ oxidase deficiency in subacute necrotizing encephalomyelopathy. J Neurol Sci 77:103-115

13. Fischer JC, Ruitenbeek W, Gabreels FJM, Janssen AJM, Reinier WO, Sengers RCA. Stadhouders AM. Ter Laak HJ, Trijbels JMF, Veerkamp JH 1986 A mitochondrial encephalomyopathy: the first case with an established defect at the level of coenzyme Q. Eur J Pediatr 144:441-444

14. Van Laack HLJM, Ruitenbeek W, Trijbels JMF, Sengers RCA. Gabreëls FJM, Janssen AJM. Kerkhof CMC 1988 Estimation of pyruvate dehydrogenase $\left(E_{1}\right)$ activity in human skeletal muscle; three cases with $E_{1}$ deficiency. Clin Chim Acta 171:109-118

15. Smeitink J, Wevers R, Hulshof J, Ruitenbeek W, van Lith J, Sengers R. Trijbels F. Walliman T, Korenke C 1992 A method for quantitative measurement of mitochondrial creatine kinase in human skeletal muscle. Ann Clin Biochem 29:196-201

16. Taylor DJ, Bore PJ, Styles P. Gadian DG, Radda GK 1983 Bioenergetics of intact human muscle: ${ }^{31}$ P-NMR study. Mol Biol Med 1:77-94

17. Arnold DL, Matthews PM, Radda GK 1984 Metabolic recovery after exercise and the assessment of mitochondrial function in vivo in human skeletal muscle by means of ${ }^{31}$ P-NMR. Magn Reson Med 1:307-315
18. Mever RA 1988 A linear model of muscle respiration explains monoexponential phosphocreatine changes. Am J Physiol 254:C548-C553

19. Van den Bogert C. Pennings A. Dekker HL, Boezeman JBM, Luciaková K. Sinjorgo KCM 1991 Quantification of mitochondrial proteins in cultured cells by immuno-flow cytometry. Biochim Biophys Acta 1097:87-94

20. Wijburg FA. Feller N, Scholte HR, Przyrembel H, Wanders RJA 1989 Studies on the formation of lactate and pyruvate from glucose in cultured skin fibroblasts: implications for detection of respiratory chain defects. Biochem Int 19:563-570

21. Wanders RJA. Meijer AJ. Groen AK. Tager JM 1983 Bicarbonate and the pathway of glutamate oxidation in isolated rat-liver mitochondria. Eur $\mathrm{J}$ Biochem 133:245-254

22. Schultheiss HP. Klingenberg M 1985 Immunoelectrophoretic characterization of the ADP/ATP carrier from heart, kidney and liver. Biochem Biohys 239:273-279

23. Schultheiss HP. Schulze K. Kühl U. Ulrich G. Klingenberg M 1986 The ADP ATP carrier as a mitochondrial auto-antigen: facts and perspectives. Ann NY Acad Sci 488:44-64

24. Lauguin GJM. Villiers C. Michejda JW. Hrniewiecka LV. Vignais PV 1977 Adenine nucleotide transport in sonic sub-mitochondrial particles: kinetic properties and binding of specific inhibitors. Biochim Biophys Acta 460:331 345

25. Engel AG 1986 Carnitine deficiency svndromes and lipid storage myopathies. In: Engel AG, Baker BQ (eds) Myology. McGraw-Hill. New York, pp 16631696

26. Scholte HR, Rodrigues Pereira R, Busch HFM, Jennekens FGI, Luyt-Houwen IEM. Vaandrager-Verduin MHM 1989 Carnitine deficiency, mitochondrial dysfunction and the heart. Identical defect of oxidative phosphorylation in muscie mitochondria in cardiomyopathy duc to camitine loss and Duchenne muscular Dystrophy. Wiener Klin Wschr 101:12-17

27. Tein I, De Vivo DC. Bierman F. Pulver P. De Meirleir LJ. Cvitanovic-Sojat L. Pagon RA, Bertini E. Dionisi-Vici C. Servidei S, DiMauro S 1990 Impaired skin fibroblast carnitine uptake in primary systemic carnitine deficiency manifested by childhood carnitine-responsive cardiomyopathy. Pediatr Res 28:247-255

28. Scholte HR. Rodrigues Pereira R, de Jonge PC. Luyt-Houwen IEM. Verduin MHM, Ross JD 1990 Primary carnitine deficiency, J Clin Chem Clin Biochem 28:351-357 